\title{
PERANCANGAN SISTEM INFORMASI AKADEMIK MADRASAH ALIYAH NEGERI (MAN) 4 KARAWANG BERBASIS WEB
}

\author{
Dian Ardiansyah'), Atang Saepudin²), Riska Aryanti'), Eka Fitriani4) \\ ${ }^{1}$ Teknik \& Informatika, Universitas Bina Sarana Informatika PSDKU Karawang, Jalan Banten No. 1, \\ Karangpawitan - Karawang \\ email: dian.did@bsi.ac.id \\ ${ }^{2}$ Teknik \& Informatika, Universitas Bina Sarana Informatika, Jl. Kramat Raya No.98, Senen - Jakarta Pusat \\ email: atang.aug@bsi.ac.id \\ ${ }^{3}$ Teknik \& Informatika, Universitas Bina Sarana Informatika, Jl. Kramat Raya No.98, Senen - Jakarta Pusat \\ email: riska.rts@bsi.ac.id \\ ${ }^{4}$ Teknik \& Informatika, Universitas Bina Sarana Informatika, Jl. Kramat Raya No.98, Senen - Jakarta Pusat \\ email: eka.ean@bsi.ac.id
}

\begin{abstract}
Abstrak
Perkembangan teknologi informasi yang berbasis web saat ini semakin tinggi. Salah satunya adalah website. Website memiliki kelebihan dimana segala informasi yang diinginkan bisa dengan mudah dan murah didapatkan. Madrasah Aliyah Negeri (MAN) Rengasdengklok atau sekarang dikenal dengan sebutan MAN 4 Karawang saat ini pengolahan data akademiknya terutama dalam pengolahan nilai masih sangat sederhana yaitu hanya dengan Microsoft excel. Hadirnya sistem informasi akademik ini yang memiliki fungsi halaman guru, siswa, jadwal mengajar, pengolahan nilai, jadwal pelajaran, hasil raport dan data siswa, diharapkan dapat membantu para guru dan para siswa untuk mendapatkan efektivitas dalam kegiatan akademik dengan lebih cepat, dan mudah. Dalam membangun sistem ini menggunakan metodologi waterfall. Perancangan dan implementasi dilakukan dengan bahasa pemrograman Dreamweaver dan PHP serta basis data yang digunakan PhpMyAdmin. Dengan adanya sistem informasi akademik ini, semoga dapat membantu untuk menunjang kinerja sekolah khususnya untuk pengolahan data akademik.
\end{abstract}

Kata kunci : Sistem Informasi, Website, Waterfall

\begin{abstract}
The development of web-based information technology is currently increasing. One of them is the website. The website has the advantage that all the information you want can be easily and cheaply obtained. Madrasah Aliyah Negeri (MAN) Rengasdengklok or now known as MAN 4 Karawang currently processing academic data, especially in processing grades is still very simple, namely only with Microsoft Excel. The presence of this academic information system is expected to help teachers and students get academic information more quickly, easily and cheaply. In building this system the writer uses the waterfall methodology. The design and implementation were carried out with the Dreamweaver programming language and PHP and the database used by PhpMyAdmin. With this academic information system, hopefully it can help to support school performance, especially for processing academic data.
\end{abstract}

Keywords: Information Systems, Website, Waterfall 


\section{PENDAHULUAN}

Pendidikan adalah salah satu faktor yang sangat penting dalam perkembangan suatu negara, semakin baik perkembangan, isi dan kualitas pendidikan suatu bangsa maka akan semakin baik pula perkembangan Negara tersebut, semakin mengerti suatu bangsa akan pentingnya suatu pendidikan maka akan semakin baik kualitas pendidikan Negara tersebut. Indonesia adalah negara yang masih dalam tahap perkembangan, tentunya dalam segala aspek dan tidak terkecuali dunia pendidikan. Saat ini kenyataan yang terjadi tentang dunia pendidikan di Indonesia masih dapat dibilang tidak terlalu baik, terutama dalam bidang pemerataan pendidikan di negara ini. Sistem pendidikan yang diterapkan kebanyakan masih memakai sistem pendidikan konvensional atau dengan sistem pendidikan cara lama yang menggunakan cara-cara manual dalam aktivitas pendidikannya baik mengenai cara pengolahan data maupun sistem akademik pendidikannya padahal di era serba teknologi ini kecepatan mengolah data dan memperoleh informasi sangat diperlukan dalam dunia pendidikan sekarang.

MAN 4 Karawang merupakan sebuah bentuk perwujudan dalam mendidik generasi muda bangsa Indonesia. Dengan perkembangan jumlah siswa yang terus bertambah dari tahun ke tahun, dituntut ketepatan dan ketelitian dalam memberikan informasi pengolahan data nilai yang tepat dan akurat kepada siswa tanpa adanya pengulangan data yang sama.

Sistem pendataan siswa yang sekarang dirasakan masih banyak kekurangan yang terjadi, dikarenakan sistem yang ada masih menggunakan lembaran kertas dan arsip sehingga dapat menyebabkan data-data yang ada hilang ataupun rusak [1]. Hal ini dapat memperlambat dan menghambat informasi-informasi bagi siswa dan guru [2], karena selama ini pengelolaan akademik yang dilakukan dan penyajian informasi berada di sekolah sehingga sangat diperlukan sistem informasi akademik berbasis web yang dapat memudahkan guru dan siswa dalam memberikan dan mendapatkan informasi secara mudah dan cepat [3].

Oleh karena itu dengan dukungan ilmu pengetahuan dan teknologi maka diperlukan sistem kerja yang cepat dengan dibuatnya sistem informasi yang lebih luas mengenai sekolah tersebut. Maka dari itu, penulis mencoba merancang sebuah website yang bertujuan untuk membantu memperlancar informasi antara pihak sekolah, siswa- siswi dan masyarakat [4]. Pemanfaatan tersebut akan mempermudah suatu pekerjaan seperti halnya pengolahan data lebih cepat, keputusan yang akan diambil lebih tepat, menghemat tempat atau ruang penyimpanan data. Selain itu, sistem informasi yang berbasis web juga dapat menjadi sarana promosi yang efisien dan sumber informasi yang dapat diakses oleh pengguna internet yang semakin lama semakin luas.

\section{TINJAUAN PUSTAKA}

\subsection{Sistem Informasi}

Sistem Informasi adalah suatu sistem didalam organisasi yang mempertemukan kebutuhan pengolahan transaksi harian, mendukung operasi, bersifat manajerial, dan kegiatan strategi dari suatu organisasi dan menyediakan pihak luar tertentu dengan laporanlaporan yang dibutuhkan [5]. Meningkatkan sistem informasi teknologi untuk mempermudah dalam proses kerja, apabila suatu perusahaan/instansi telah menggunakan teknologi yang sekarang untuk kegiatannya maka akan dapat dikatakan pengolahan kegiatan dapat dilaksanakan dengan maksimal [6]. 


\subsection{Sistem Informasi Akademik}

Perkembangan dalam penggunaan sistem informasi akademik ini biasanya berbasis web, artinya dapat diakses melalui jaringan intranet atau internet/online, serta dapat diintegrasikan dengan sistem-sistem lainnya, seperti E-Learning, SMS Akademik, Sistem Informasi Perusahaan, Sistem Informasi Kepegawaian, Sistem Informasi Aset, serta Sistem Informasi Monitoring \& Evaluasi [7] .

\subsection{Penelitian Terdahulu}

Berdasarkan penelitian terdahulu dengan menggunakan referensi dari jurnal-jurnal ilmiah dari beberapa sumber penelitian yang sudah dilakukan sebagai berikut :

Penelitian yang dilakukan oleh [8], dalam jurnal yang berjudul "Aplikasi Web Untuk Sistem Informasi Akademik SMA Negeri 33 Jakarta" menyimpulkan bahwa: Sistem informasi akademik dapat membantu memberikan informasi yang mempunyai sifat online dalam efisiensi waktu, yaitu dapat diakses dimana saja dan kapan saja dibutuhkan sehingga pihak yang berwenang dan membutuhkan informasi tidak mengalami kesulitan untuk memperolehnya dan efektif.

Penelitian yang dilakukan oleh [9], dalam jurnal yang berjudul "Sistem Informasi Akademik Berbasis Web Menggunakan Model Waterfall Pada SMK ITENAS Karawang" menyimpulkan bahwa: sistem informasi akademik merupakan sarana komunikasi bagi siswa, guru dan pihak sekolah untuk memperoleh informasi mengenai segala sesuatu yang berhubungan dengan sistem proses belajar mengajar. Memberikan kemudahan kepada siswa untuk mendapatkan informasi mengenai kesiswaan, yaitu seperti jadwal pelajaran, nilai dan informasi-informasi terbaru yang diterbitkan oleh pihak sekolah.

Penelitian yang dilakukan oleh [10], dalam jurnal yang berjudul "Rancang Bangun Sistem Informasi Akademik Berbasis Web pada Madrasah Aliyah Attaqwa Tangerang" menyimpulkan bahwa: Sistem Informasi Akademik ini akan mengelola data siswa, guru, nilai dan informasi sekolah yang akan disampaikan kepada masyarakat luar dengan lebih efektif dan memiliki ruang lingkup yang lebih luas dalam proses penyaluran informasi.

Penelitian yang dilakukan oleh [11], dalam jurnal yang berjudul "Perancangan Sistem Informasi Akademik Berbasis Website Pada SMK Bina Medika Jakarta" menyimpulkan bahwa: sistem informasi akademik untuk mempermudah siswa, guru dan pihak Sekolah Menengah Kejuruan (SMK) Bina Medika yang sebelumnya belum tersedia, data siswa, data guru dan pihak sekolah masih terpisah sehingga untuk mengetahui informasi lengkap cukup lama, dengan ada nya sistem informasi berbasis website yang online diharapkan dapat mempermudah siswa, guru dan pihak SMK Bina Medika, sehingga dapat lebih efektif dan efisien.

\section{METODE PENELITIAN}

\subsection{Metode Pengembangan Perangkat Lunak}

Metode ini merupakan metode yang sering digunakan oleh penganalisa sistem pada umumnya. "Model waterfall sering disebut siklus hidup klasik, menunjukkan sistematis, pendekatan yang sekuensial untuk pengembangan perangkat lunak yang diawali dengan spesifikasi pelanggan persyaratan dan berkembang melalui perencanaan, pemodelan, konstruksi, dan penyebaran, yang berpuncak pada dukungan yang berkelanjutan dari perangkat lunak yang lengkap [12].

Adapun langkah-langkah Model waterfall adalah : 


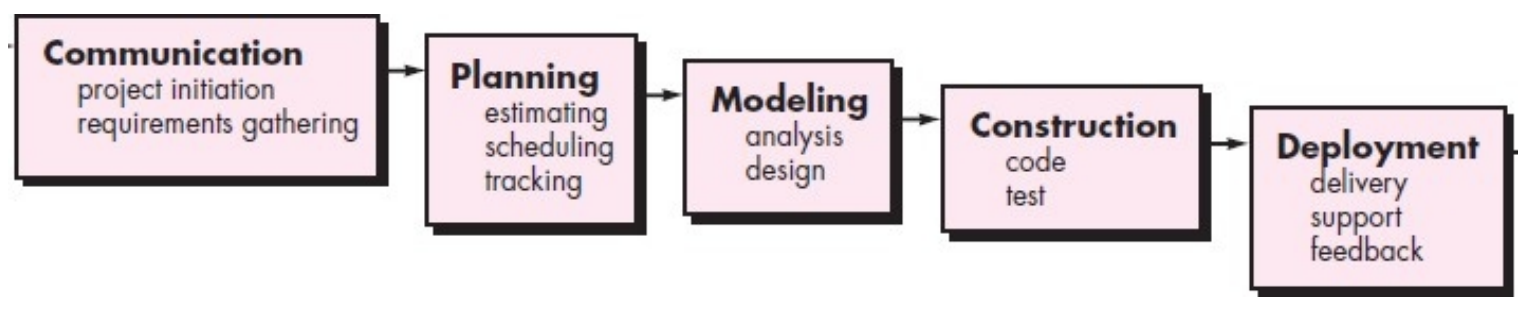

Sumber: Pressman (2010:39)

Gambar 3. 1 Model Waterfall

a. Communication

Langkah ini merupakan analisis terhadap kebutuhan software, dan tahap untuk mengadakan pengumpulan data dengan melakukan pertemuan dengan pihak MAN 4 Karawang, maupun mengumpulkan data-data tambahan baik yang ada di jurnal, artikel, maupun dari internet.

b. Planning

Proses planning merupakan lanjutan dari proses communication (analysis requirement). Tahapan ini akan menghasilkan dokumen user requirement atau bisa dikatakan sebagai data yang berhubungan dengan keinginan user dalam pembuatan software, termasuk rencana yang akan dilakukan.

c. Modeling

Proses modeling ini akan menerjemahkan syarat kebutuhan ke sebuah perancangan software yang dapat diperkirakan sebelum dibuat coding. Proses ini berfokus pada rancangan struktur data. Arsitektur software, representasi interface, dan detail (algoritma) procedural. Tahapan ini akan menghasilkan dokumen yang disebut software requirement.

d. Construction

Construction merupakan proses membuat kode. Coding atau pengkodean merupakan penerjemahan desain dalam bahasa yang bisa di kenali oleh komputer. Programmer akan menerjemahkan transaksi yang diminta oleh user. Tahapan inilah yang merupakan tahapan secara nyata dalam mengerjakan suatu software, artinya penggunaan komputer akan dimaksimalkan dalam tahapan ini. Setelah pengkodean selesai maka akan dilakukan testing terhadap sistem yang telah dibuat tadi. Tujuan testing adalah menemukan kesalahan-kesalahan terhadap sistem tersebut untuk demikian bisa diperbaiki.

e. Deployment

Tahapan ini bisa dikatakan final dalam pembuatan sebuah software atau sistem. Setelah melakukan analisis, desain dan pengkodean maka sistem yang sudah jadi akan digunakan oleh user. Kemudian software yang telah dibuat harus dilakukan pemeliharaan secara berkala.

\subsection{Teknik Pengumpulan Data}

Untuk mendapatkan data-data yang diperlukan, maka penulis menggunakan beberapa metode,yaitu:

1. Observasi

Observasi pada MAN 4 Karawang, dengan maksud agar dapat lebih memahami proses sistem akademik yang sedang berjalan di sekolah yang masih menggunakan sistem manual, baik itu data guru, data siswa, jadwal pelajaran, penginputan nilai, pengumaman dan yang lainnya yang masih menggunakan sistem manual.

2. Wawancara 
Wawancara dilakukan dengan mengajukan beberapa pertanyaan kepada Kepala Madrasah Bpk. Drs. H. Ilin Nuryadin, M.Pd.I, Waka Kurikulum Bpk. Muhasan, S.Ag dan bagian Tata Usaha terkait proses belajar mengajar siswa dan guru, mulai dari jadwal mengajar guru, jadwal pelajaran dan proses penilaian siswa oleh guru yang mata pelajaran masing-masing.

3. Studi Pustaka

Mengumpulkan data dan studi kepustakaan (Library Research) yaitu dengan membaca bukubuku, jurnal dan referensi data yang lainnya di internet yang berkaitan dengan kebutuhan.

\subsection{Ruang Lingkup}

Sistem informasi akademik berbasis web dibangun dengan menggunakan bahasa pemrograman web HTML \& PHP serta database MySQL. Website ini terbagi 3 level pengguna, ruang lingkup admin bisa menambah, melihat, mengedit dan menghapus : data siswa, guru, mata pelajaran, kelas, pembagian kelas, nilai, jadwal pelajaran, kalender akademik, content, artikel, dan hanya bisa melihat dan menghapus buku tamu. Untuk ruang lingkup guru bisa melihat data pribadi, ganti password, melihat dan mencetak jadwal mengajar, input nilai (menginput, melihat, mengupdate dan menghapus), dan melihat kalender akademik. Dan untuk ruang lingkup siswa yaitu melihat data pribadi, ganti password, melihat dan mencetak jadwal pelajaran, melihat nilai uts, melihat nilai uas, dan melihat dan mencetak Rapor siswa. Website ini bersifat intern yang artinya pengguna program ini hanya kalangan tertentu yang memiliki akses terhadap program akademik, sedangkan pengunjung hanya bisa melihat informasi umum dan kegiatan-kegiatan yang berkaitan dengan MAN 4 Karawang.

\subsection{Tahapan Pengembangan Sistem}

Analisa sistem didefinisikan sebagai bagaimana memahami dan menspesifikasikan dengan detail apa yang harus dilakukan oleh sistem. Proses- proses standar yang digunakan untuk membangun suatu sistem informasi meliputi langkah-langkah berikut ini:

1. Analisa Kebutuhan Software

Menganalisa permasalahan yang terjadi untuk dapat menemukan jawaban apa penyebab masalah-masalah yang timbul. Dalam perkembangannya sekolah tersebut belum ada media yang menciptakan proses pengolahan dan penginformasian data yang efektif, efisien dan modern, seperti sistem informasi akademik berbasis web yang mampu memberikan kemudahan untuk pemakainya. Dalam hal ini, pemakainya antara lain adalah waka kurikulum, para guru dan para siswa. Pengolahan nilai siswa di MAN 4 Karawang ini masih menggunakan teknik pencatatan manual. Teknik ini menghadapi kendala yang berkaitan dengan keterbatasan tempat, lokasi dan waktu. Proses pengolahan nilai saat ini cenderung lebih merepotkan staff, baik pengajar, staff Tata Usaha ataupun staff kurikulum karena tidak bisa dilakukan diluar dari lingkungan sekolah, sehingga perlu dibuatkan sebuah sistem komputerisasi berbasis web. Dengan sistem tersebut, diharapkan agar proses pengolahan nilai bisa lebih baik dan lebih memudahkan para staff yang ada di lingkungan MAN 4 Karawang.

2. Desain

Desain dan pembuatan aplikasi berkonsentrasi pada bagaimana sistem dibangun untuk memenuhi kebutuhan pada fase analisis, membangun perangkat lunak untuk mendukung sistem meliputi desain sistem dengan menggunakan UML (use 
case diagrams, activity diagrams, sequence diagrams dan deployment diagrams.), mendesain user interface, manajemen user, manajemen file, membuat rancangan input output dan membuat rancangan keamanan web. Dan untuk desain programnya menggunakan Entity Relationship Diagram (ERD) dan Logical Record Structure (LRS).

3. Code Generation

Mendeskripsikan pearancangan sistem yang penulis usulkan pada permasalahan yang ada dengan menjabarkan semua perintah-perintah listing atau coding yang digunakan untuk pengolahan data yang ada dalam pembuatan Web Sistem Informasi Akademik pada MAN 4 Karawang yang kemudian dapat dikompile menggunakan server local (localhost) dan sistem yang digunakan yaitu terstruktur.

4. Testing

Pengujian program yang sudah dibuat kedalam sistem yang sudah ada merupakan suatu proses pengubahan dari hasil perancangan sistem yang berbasis web PHP, dalam hal ini penulis menggunakan Black Box Testing.

\section{Support}

Dalam mengakses website yang penulis buat diperlukan adanya menghosting. Web hosting yang penulis gunakan yaitu berbayar.

\section{HASIL DAN PEMBAHASAN}

\subsection{Rancangan Sistem Usulan}

Rancangan sistem usulan dalam membangun Website Sekolah ini diperlukan untuk memberikan gambaran langkah demi langkah dalam pembuatan sistem informasi. Beberapa tools digunakan untuk perancangan program diantaranya:

\subsubsection{Activity Diagram}

Activity Diagram digunakan untuk model perilaku dalam independen proses bisnis Suatu objek. Dalam banyak hal, Activity Diagram dapat dipandang sebagai diagram aliran data yang canggih yang dapat digunakan dalam hubungannya dengan analisis terstruktur [13].

\section{Prosedure Mengajar Guru}

Wakamad Kurikulum membuat jadwal mengajar guru dan diserahkan kepada Kepala Madrasah. Setelah mendapat persetujuan dari Kepala Madrasah, jadwal mengajar diberikan kepada guru pengajar. .Berikut ini Activity Diagram Informasi Mengajar Guru : 


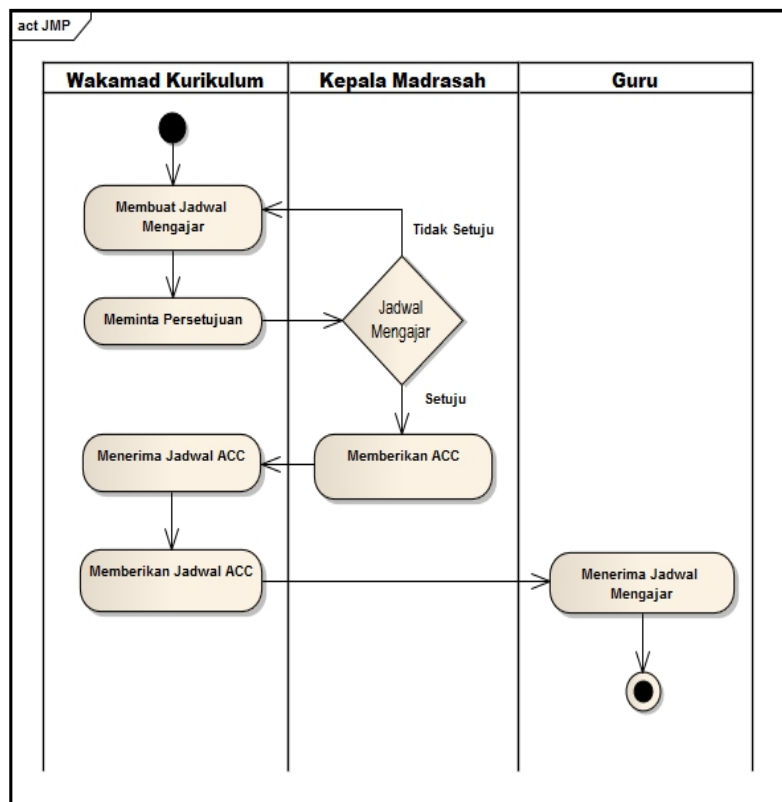

Gambar 4.1 Activity Diagram Informasi Mengajar Guru

2. Prosedur Jadwal Mata Pelajaran

Wakamad Kurikulum membuat jadwal pelajaran untuk setiap kelas, setelah itu memberikan ke kepala Madrasah untuk meminta persetujuan. Setelah mendapat persetujuan dari Kepala Madrasah, jadwal Pelajaran didistribusikan kepada para siswa.

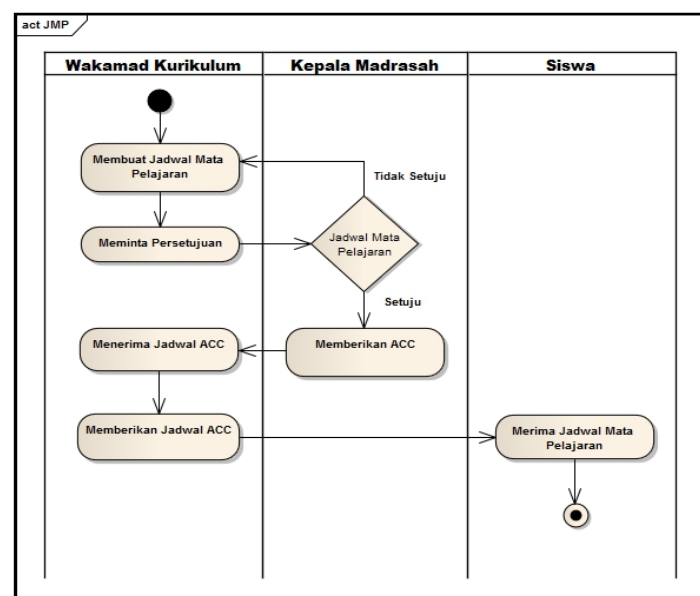

Gambar 4.2 Activity Diagram Jadwal Mata Pelajaran

3. Informasi Nilai

Setelah siswa melakukan ujian, maka guru akan memberikan nilai kepada Wali Kelas kemudian wali kelas mengisi Raport Sementara sebagai bayangan dari nilai raport dan kemudian diserahkan kepada siswa. 
Hal : $187-201$

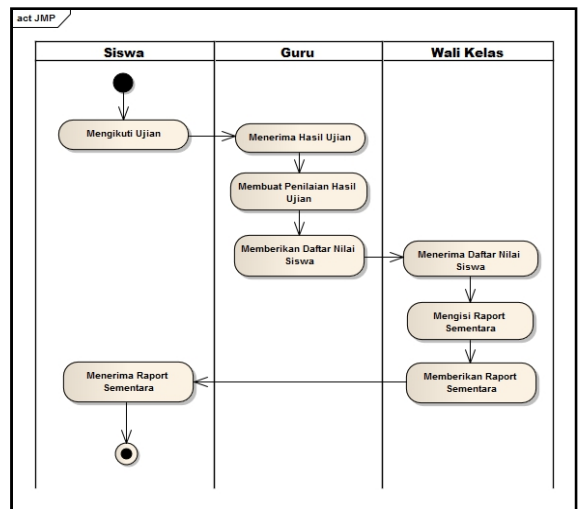

Gambar 4.3 Activity Diagram Informasi Nilai Siswa

\subsubsection{Use Case Diagram}

Use Case secara defitif sesungguhnya merupakan "urutan aksi-aksi (sering juga disebut sebagai flow-of-events) yang akan dilakukan sistem atau perangkat lunak untuk memberikan hasil atau nilai tertentu pada masing-masing actor [14] ".

1. Use Case Diagram Halaman Admin Mengelola Data Mata Pelajaran

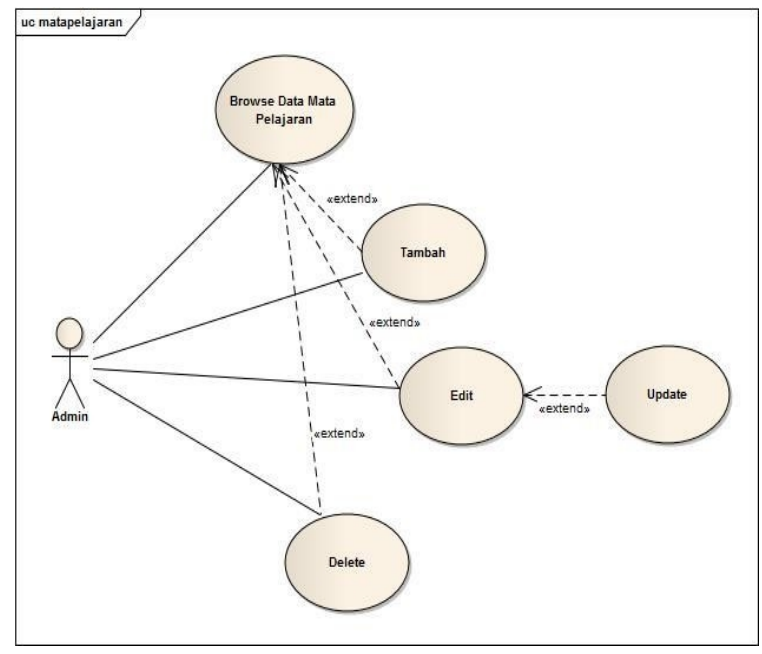

Gambar 4.4 Use Case Diagram Halaman Admin Mengelola Data Mata Pelajaran

2. Use Case Diagram Halaman Admin Mengelola Data Jadwal Mengajar Guru

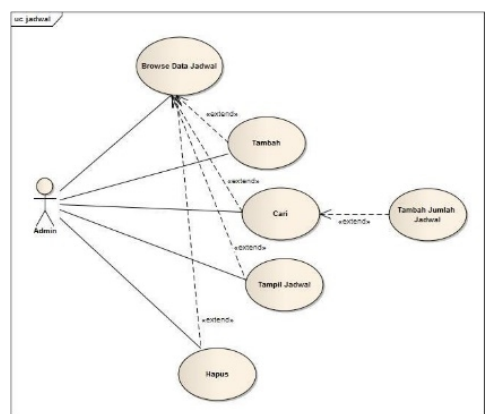

Gambar 4.5 Use Case Diagram Halaman Admin 
Hal : 187 - 201

Mengelola Data Jadwal Mengajar Guru

3. Use Case Diagram Halaman Admin Mengelola Data Nilai Siswa

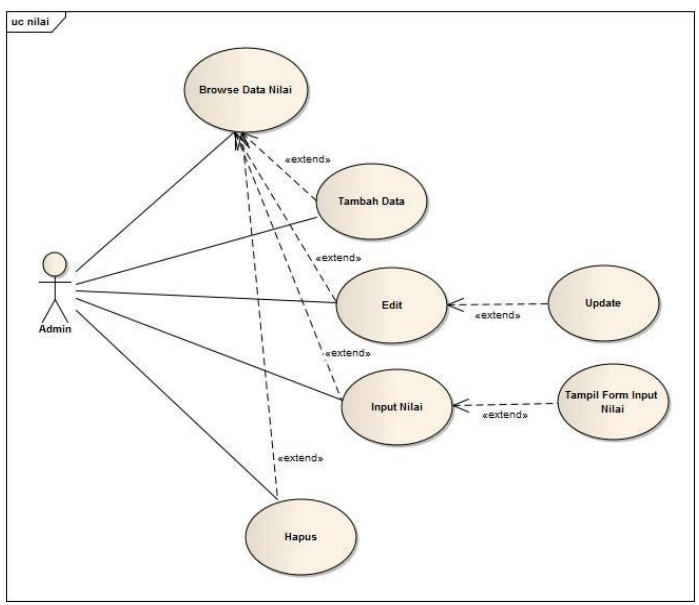

Gambar 4.6 Use Case Diagram Halaman Admin Mengelola Data Nilai Siswa

4. Use Case Diagram Halaman Guru Melihat dan Mencetak Data Jadwal Mengajar

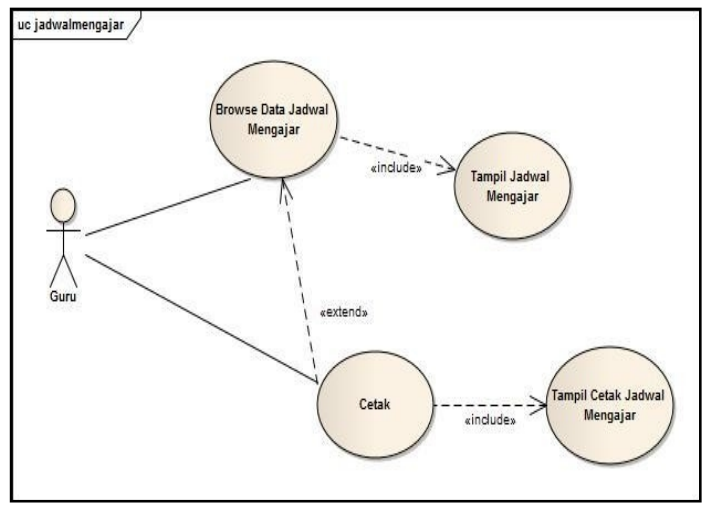

Gambar 4.7 Use Case Diagram Halaman Guru Melihat dan Mencetak Data Jadwal Mengajar

5. Use Case Diagram Halaman Guru Mengelola Nilai Siswa

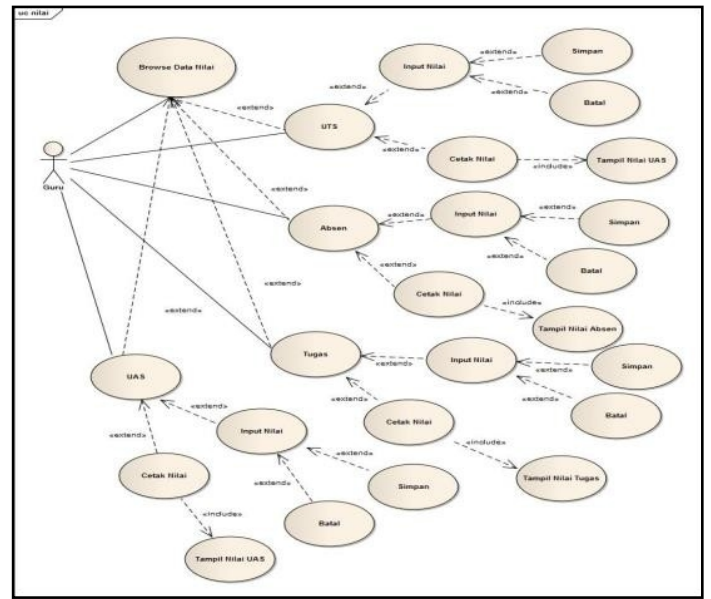

Gambar 4.8 Use Case Diagram Halaman Guru

Mengelola Nilai Siswa 
Hal : $187-201$

6. Use Case Diagram Halaman Siswa Melihat dan Mencetak Jadwal Pelajaran

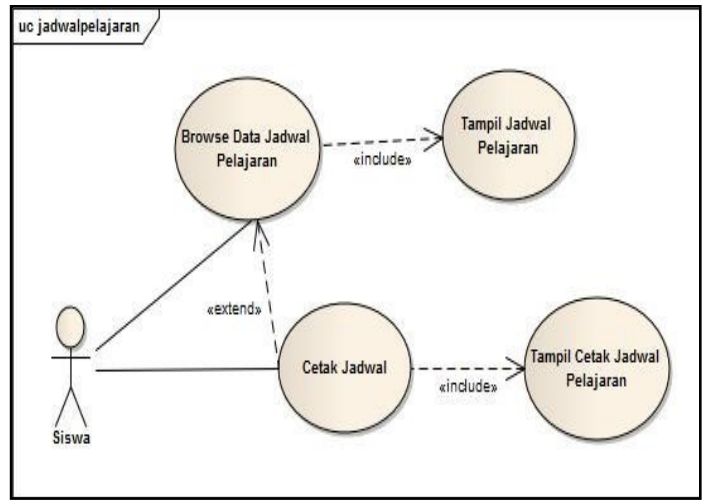

Gambar 4.9 Use Case Diagram Halaman Siswa Melihat dan Mencetak Jadwal Pelajaran

7. Use Case Diagram Halaman Siswa Melihat dan Mencetak Rapor Siswa

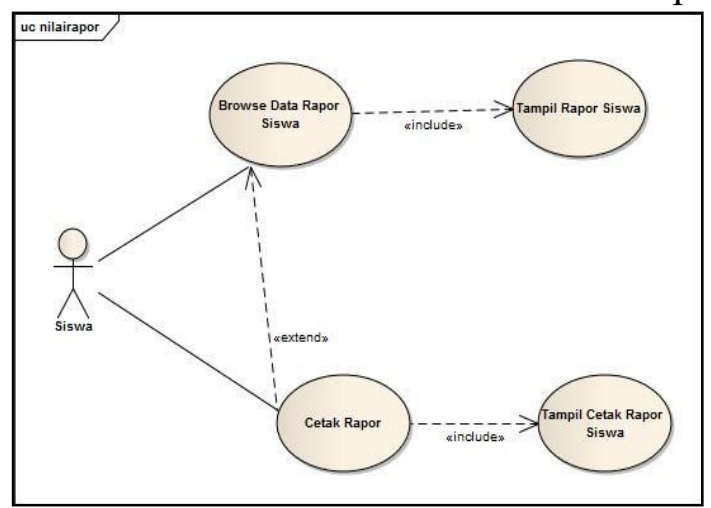

Gambar 4.10 Use Case Diagram Halaman Siswa

Melihat dan Mencetak Rapor Siswa

\subsubsection{Rancangan Database}

Entity Relation Diagram (ERD) atau yang dikenal juga dengan Diagram EntityRelationship (Diagram E-R) merupakan suatu model yang menjelaskan hubungan antar data dalam basis data berdasarkan objek-objek dasar data yang mempunyai hubungan antar relasi.

Model Entity-Relationship yang berisi komponen-komponen himpunan entitas dan himpunan relasi yang masing-masing dilengkapi dengan atribut- atribut yang mempresentasikan seluruh fakta dari dunia nyata yang kita tinjau, dapat digambarkan dengan lebih sistematis dengan menggunakan Diagram Entity-Relationship [15]. Dalam perancangan database Website Akademik dibutuhkan beberapa entitas yang memiliki keterkaitan sehingga dapat dilakukan sebuah pengelolaan database. 
$\mathrm{Hal}: 187-201$

\subsection{HASIL}

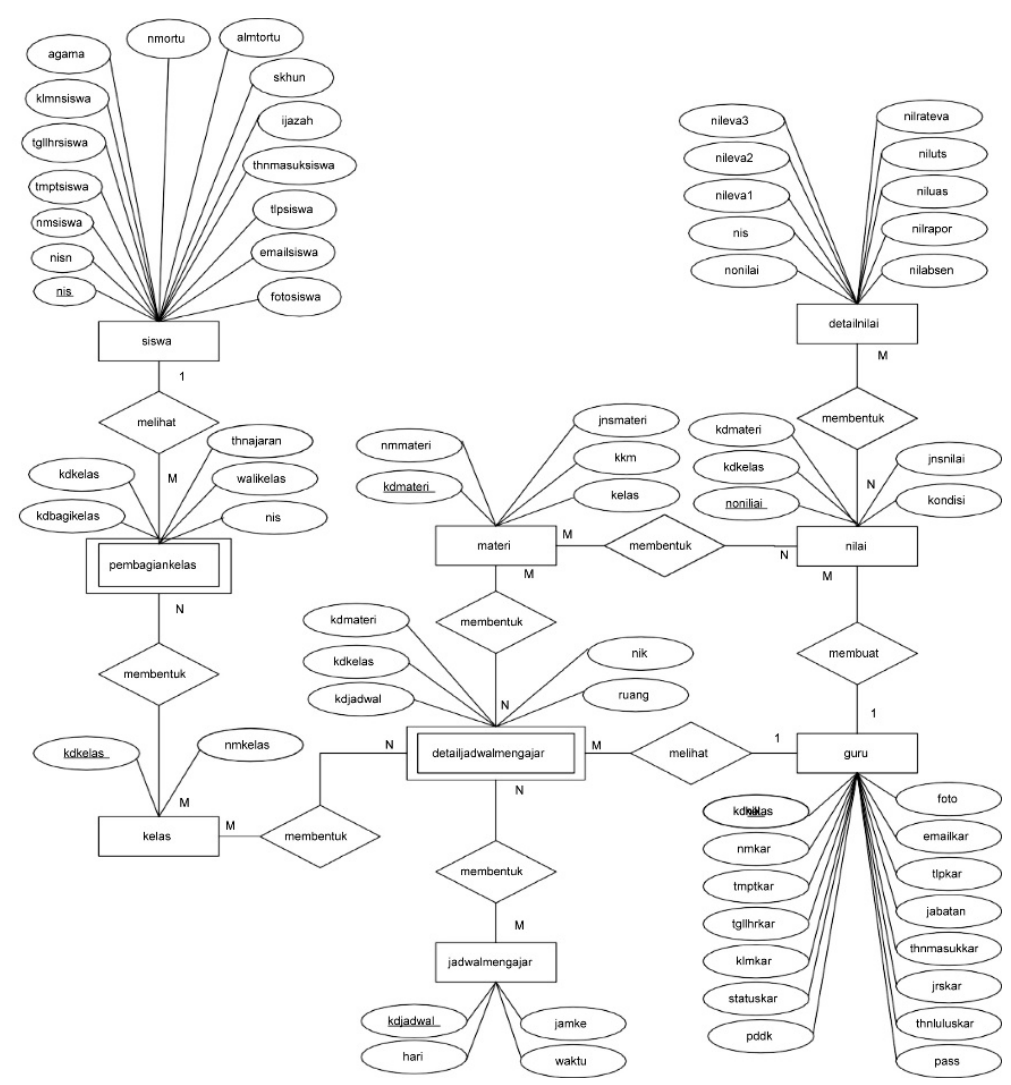

Gambar 4.11 Entity Relationship Diagram

\subsubsection{Implementasi Sistem}

Mengimplementasikan Perancangan Website Sistem Informasi Akademik pada siswa/i dan guru di MAN 4 Karawang dilakukan untuk mendapatkan evaluasi berikut pengembangan sebuah Sistem Informasi Akademik yang diterapkan. Penerapan rancangan program yang dilakukan sesuai dengan tahapan model pengembangan sistem yang sudah diuraikan. Hasil dari penerapan tersebut adalah berupa Sistem Informasi Akademik Berbasis Website yang dapat digunakan pengguna berikut adalah tampilan halaman sistem informasi Akademik MAN 4 Karawang:

1. Halaman Home

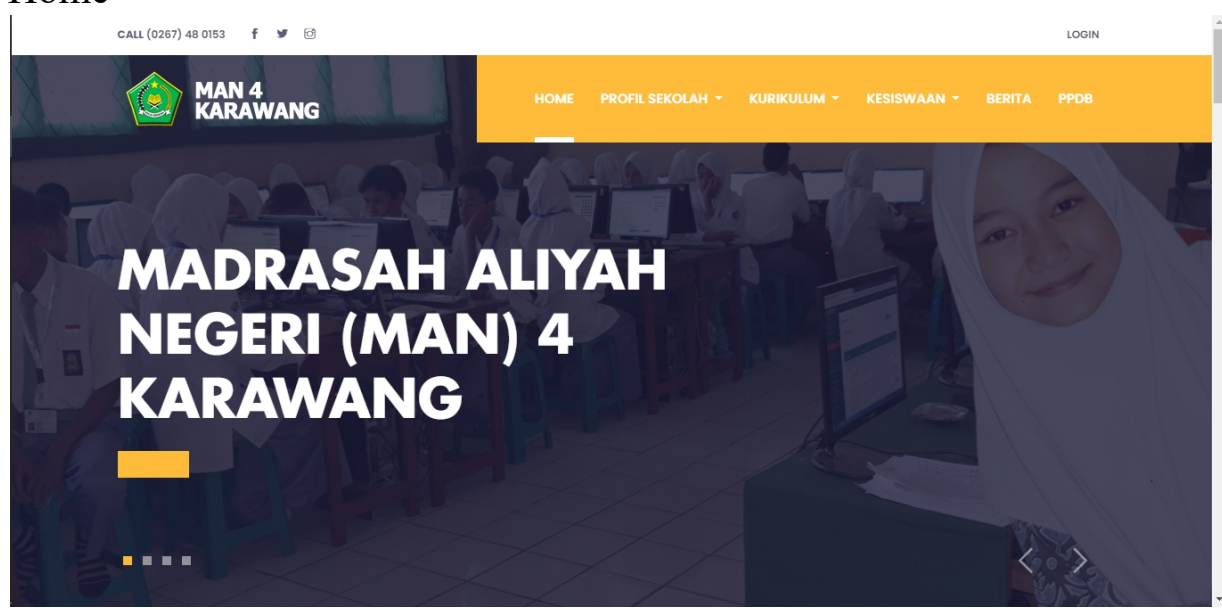

Gambar 4.12 Halaman Home 
Hal : $187-201$

2. Halaman Beranda Siswa

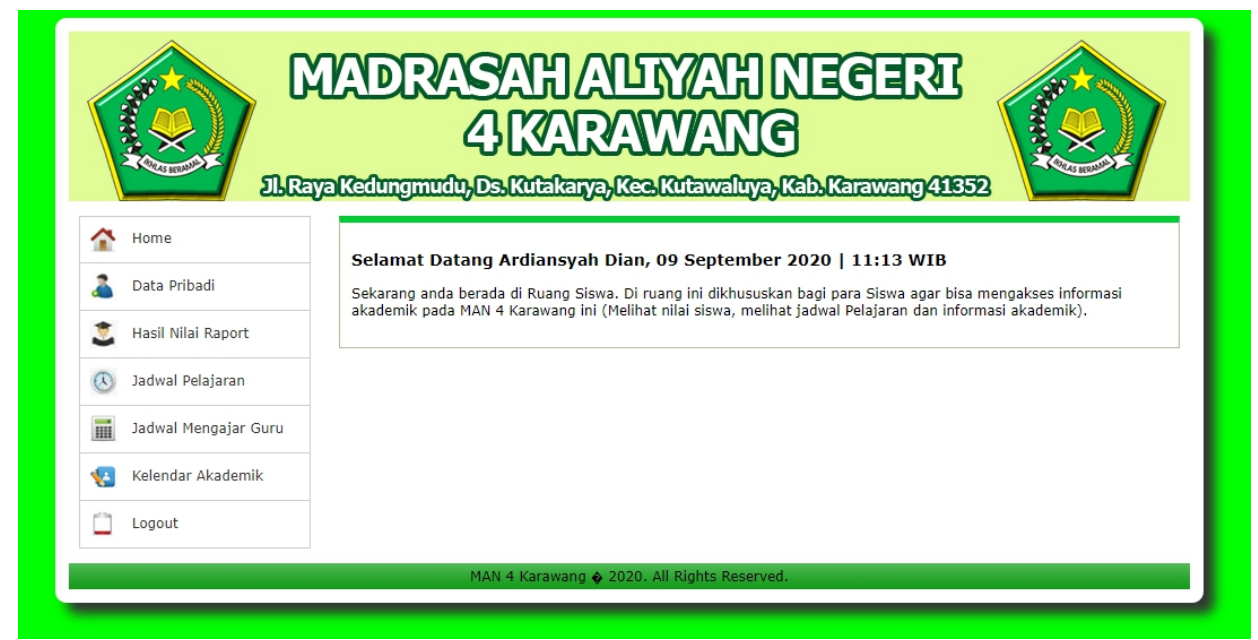

Gambar 4.13 Halaman Beranda Siswa

3. Halaman Data Pribadi Guru

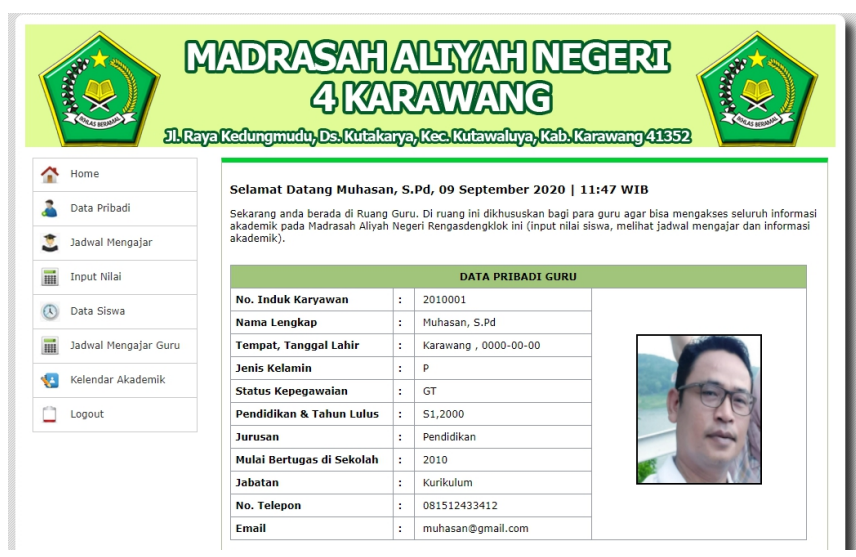

Gambar 4.14 Halaman Data Pribadi Guru

4. Halaman Mengajar Guru

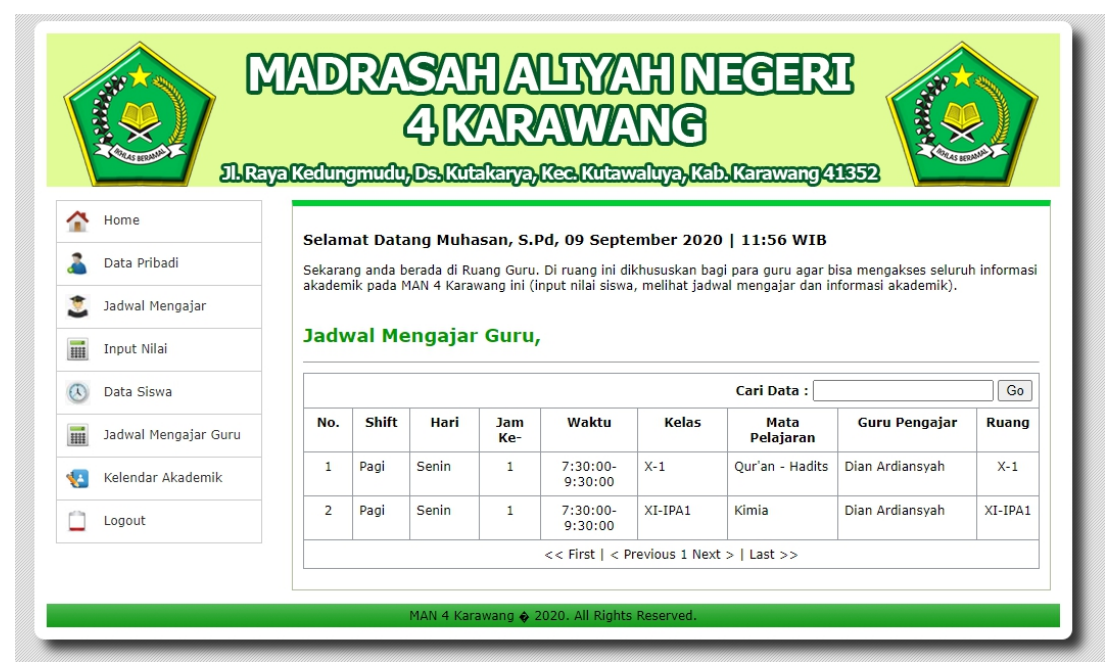

Gambar 4.15 Halaman Mengajar Guru 


\subsubsection{Pengujian Unit}

Pengujian web diperlukan untuk penilaian dari keberhasilan program pembuatan web agar dapat segera diketahui kelemahan atau fungsi dari web yang dibuat.

Black Box Testing adalah pengujian dilakukan dalam bentuk tertulis untuk memeriksa apakah aplikasi berjalan seperti yang diharapkan [16]. Berikut ini pengujian dari program Sistem Informasi Akademik MAN 4 Karawang :

\begin{tabular}{|c|c|c|c|c|}
\hline No & Fungsi yang diuji & Cara Pengujian & Hasil yang diharapakan & $\begin{array}{l}\text { Hasil } \\
\text { Pengujian }\end{array}$ \\
\hline 1 & Halaman Login & $\begin{array}{l}\text { Terdapat } 3 \\
\text { pengguna pada } \\
\text { halaman ini } \\
\text { yaitu admin, } \\
\text { guru, dan siswa. } \\
\text { Username : NIK } \\
\text { (guru \& admin) } \\
\text { dan NIS (siswa) } \\
\text { dan Password }\end{array}$ & $\begin{array}{l}\text { Admin, guru dan siswa } \\
\text { dapat masuk ke sistem } \\
\text { dengan } \\
\text { menggunakan username } \\
\text { dan password }\end{array}$ & $\mathrm{OK}$ \\
\hline 2 & Halaman Admin & $\begin{array}{l}\text { Admin login } \\
\text { sebagai } \\
\text { pengeloa sistem } \\
\text { dan dapat } \\
\text { menupdate data } \\
\text { guru, siswa, } \\
\text { jadwal } \\
\text { pelajaran, data } \\
\text { kelas, data nilai, } \\
\text { kalender } \\
\text { akademik, } \\
\text { content dan } \\
\text { artikel }\end{array}$ & $\begin{array}{l}\text { Admin dapat login dan } \\
\text { mengelola data guru, } \\
\text { siswa, jadwal pelajaran, } \\
\text { data kelas, data nilai, } \\
\text { kalender akademik, } \\
\text { content dan artikel }\end{array}$ & $\mathrm{OK}$ \\
\hline 3 & Halaman Guru & $\begin{array}{l}\text { Guru login ke } \\
\text { halaman Jadwal } \\
\text { Mengajar, Input } \\
\text { Nilai, Data } \\
\text { Siswa, Kalender } \\
\text { Akdemik }\end{array}$ & $\begin{array}{l}\text { Guru dapat melihat } \\
\text { Jadwal Input Nilai, Data } \\
\text { Siswa, } \\
\text { Akdemik }\end{array}$ & $\mathrm{OK}$ \\
\hline 4 & Halaman Siswa & $\begin{array}{l}\text { Siswa login ke } \\
\text { halaman untuk } \\
\text { melihat hasil } \\
\text { nilai raport, } \\
\text { jadwal } \\
\text { pelajaran, } \\
\text { jadwal mengajar } \\
\text { guru dan }\end{array}$ & $\begin{array}{l}\text { Siswa dapat melihat } \\
\text { hasil nilai raport, jadwal } \\
\text { pelajaran, jadwal } \\
\text { mengajar guru dan } \\
\text { kalender akademik }\end{array}$ & $\mathrm{OK}$ \\
\hline
\end{tabular}




\begin{tabular}{llll}
\hline \multicolumn{5}{c}{$\begin{array}{l}\text { kalender } \\
\text { akademik }\end{array}$} \\
\hline 5 & Halaman & Input & Guru memilih Guru dapat input nilai OK \\
& Nilai & menu input nilai absen tugas, uts dan uas \\
& absen tugas, uts sesuai mata pelajaran \\
& dan uas sesuai \\
& mata pelajaran \\
\hline
\end{tabular}

\section{SIMPULAN}

Kesimpulan dari hasil perancangan Sistem Informasi Akademik Berbasis Website di MAN 4 Karawang sebagai berikut :

1. Diera sekarang ini sangat penting sekali bagi sekolah mempunyai sistem informasi berbasis website untuk mempermudah guru maupun siswa dalam berkomunikasi secara online dan mempercepat informasi.

2. Saat ini Belum banyak sekolah-sekolah di wilayah Karawang yang menggunakan sistem informasi akademik berbasi website. Dengan sistem seperti ini kegiatankegiatan sekolah dapat dikelola dan dipantau lebih rapih secara mudah dan terpusat.

3. Dalam membangun sistem informasi akademik berbasis website ini memerlukan beberapa aplikasi editor seperti Adobe Dreamweaver atau Sublime, dan Web server sepeti MySql, Oracle dan lain-lain.

\section{UCAPAN TERIMAKASIH}

Dengan berakhirnya penelitian ini, saya ucapakan terimakasih kepada semua pihakpihak yang terlibat karena tidak akan terlaksana tanpa adanya pihak-pihak yang memberikan dukungan penuh. Terima kasih juga yang sebesar-besarnya kepada Pihak sekolah MAN 4 Karawang khususnya kepada Bapak Drs. H. Ilin Nuryadin, M.Pd.I selaku Kepala MAN 4 Karawang dan Bapak Muhasan, S.Ag selaku Waka Kurikulum beserta semua bapak/ibu guru MAN 4 Karawang.

\section{DAFTAR PUSTAKA}

[1] A. Setiyawan and B. E. Purnama, "Pembuatan Sistem Informasi Akademik Berbasis Web Pada Sekolah Menengah Atas Negeri 1 Ngadirojo," IJNS-Indonesian J. Netw. Secur., vol. 4, no. 3, 2013.

[2] T. Kurnia, D. D. S. Fatimah, and A. D. Supriatna, "Perancangan Sistem Informasi Akademik Nilai Siswa Berbasis Web (Studi Kasus: SMK Ciledug Al-Musaddadiyah Garut)," J. Algoritm., vol. 9, no. 1, pp. 145-153, 2012.

[3] E. Fitriani, D. Firmansyah, R. Aryanti, and W. Walim, "IMPLEMENTASI MODEL WATERFALL PADA SISTEM INFORMASI AKADEMIK BERBASIS WEB PADA SMK PERTANIAN KARAWANG," J. Techno Nusa Mandiri, vol. 15, no. 2, pp. 114-137, 2018.

[4] M. Susanti, "Perancangan Sistem Informasi Akademik Berbasis Web Pada Smk Pasar Minggu Jakarta,” J. Inform., vol. 3, no. 1, 2016. 
[5] Y. S. Mulyati, "Konsep Sistem Informasi," J. Adm. Pendidik., vol. 3, no. 1, 2005.

[6] S. Alfarizi, A. R. Mulyawan, D. Gunawan, and R. Aryanti, "IMPLEMENTASI UNIFIED MODELLING LANGUAGE PADA SISTEM INFORMASI NASGOR DELIVERY BERBASIS WEB," J. Interkom J. Publ. Ilm. Bid. Teknol. Inf. dan Komun., vol. 15, no. 2, pp. 42-52, 2020.

[7] T. Sutabri, Konsep sistem informasi. Penerbit Andi, 2012.

[8] N. Hidayatun, Herlawati, and Frieyadi, "Aplikasi Web Untuk Sistem Informasi Akademik Sma Negeri 33 Jakarta," pilar Nusa Mandiri, vol. Vol. IX, no. 2, p. No.2, 2014.

[9] D. Wijayanti and A. Prasetyo, "Sistem Informasi Akademik Berbasis Web Menggunakan Model Waterfall Pada SMK ITENAS Karawang," J. Inform., vol. 6, no. 1, pp. 62-68, 2019.

[10] A. Yani, A. Syauki, and S. Marlina, "Rancang Bangun Sistem Informasi Akademik Berbasis Web pada Madrasah Aliyah Attaqwa Tangerang," J. Inform., vol. 6, no. 2, pp. 255-261, 2019.

[11] T. Rahman, A. B. Pramastya, and H. Nurdin, "Perancangan Sistem Informasi Akademik Berbasis Website Pada SMK Bina Medika Jakarta,” 2019.

[12] R. S. Pressman, "Software Engineering-A Practitioner's Approach.” McGraw-Hill, 2010 .

[13] A. Dennis, B. H. Wixom, and D. Tegarden, Systems Analysis and Design UML Version 2.0. Wiley, 2009.

[14] A. Nugroho, Rekayasa perangkat lunak berorientasi objek dengan metode USDP. Penerbit Andi, 2010.

[15] B. D. Fathansyah, "Penerbit Informatika." Bandung, 2007.

[16] J. Simarmata, Rekayasa web. Penerbit Andi, 2010. 